\title{
A SELDI-TOF approach to ecotoxicology: comparative profiling of low molecular weight proteins from a marine diatom exposed to CdSe/ZnS quantum dots
}

\author{
Francesca Scebba ${ }^{\mathrm{a}, *, 1}$, Danika Tognotti ${ }^{\mathrm{b}, 1}$, Gianluca Presciuttini $^{\mathrm{b}}$, Edi Gabellieri ${ }^{\mathrm{b}}$, \\ Patrizia Cioni $^{\mathrm{b}}$, Debora Angeloni ${ }^{\mathrm{a}}$, Barbara Basso ${ }^{\mathrm{b}}$, Elisabetta Morelli ${ }^{\mathrm{b}}$ \\ a Institute of Life Sciences, Scuola Superiore Sant'Anna, Piazza Martiri della Libertà 33, 56127 Pisa, Italy \\ ${ }^{\mathrm{b}}$ National Research Council - Institute of Biophysics, Section of Pisa, Via Moruzzi, 1, 56124 Pisa, Italy
}

\section{A R T I C L E I N F O}

\section{Article history:}

Received 10 April 2015

Received in revised form

19 August 2015

Accepted 21 August 2015

Available online 29 August 2015

Keywords:

Nanoparticles

Phaeodactylum tricornutum

SELDI-TOF-MS

Biomarkers

Microalgae

\begin{abstract}
A B S T R A C T
Quantum dots (QDs), namely semiconductor nanocrystals, due to their particular optical and electronic properties, have growing applications in device technology, biotechnology and biomedical fields. Nevertheless, the possible threat to human health and the environment have attracted increasing attention as the production and applications of QDs increases rapidly while standard evaluation of safety lags.

In the present study we performed proteomic analyses, by means of 2D gel electrophoresis and Surface Enhanced Laser Desorption Ionization-Time of Flight-Mass Spectrometry (SELDI-TOF-MS). We aimed to identify potential biomarkers of exposure to CdSe/ZnS quantum dots. The marine diatom Phaeodactylum tricornutum exposed to $2.5 \mathrm{nM}$ QDs was used as a model system. Both 2DE and SELDI showed the presence of differentially expressed proteins. By Principal Component Analysis (PCA) we were able to show that the differentially expressed proteins can discriminate between exposed and not exposed cells. Furthermore, a protein profile specific for exposed cells was obtained by SELDI analysis. To our knowledge, this is the first example of the application of SELDI technology to the analysis of microorganisms used as biological sentinel model of marine environmental pollution.
\end{abstract}

(c) 2015 Elsevier Inc. All rights reserved.

\section{Introduction}

In the last two decades, colloidal semiconductor quantum dots have received extraordinary attention for their unique optical and electronic properties. Accordingly, they are increasingly used for applications in manufacturing magnetic storage media, solar energy transformation and electronics (Dow and Huang, 1996; Smyder and Krauss, 2011), as probes in biological imaging and as therapeutic tools for drug/gene delivery (Kim et al., 2010). On the other hand, as a consequence of the strong demand for nanoparticles, a substantial amount of them could be released into the environment, from soil to aquatic systems. Therefore adequate studies of their environmental fate and ecological impact should be performed, and their effects on biota need to be addressed.

Environmental monitoring consist in the evaluation of environmental quality by measuring a set of selected parameters on

\footnotetext{
* Corresponding author. Fax: + 390503152166 .

E-mail address: f.scebba@sssup.it (F. Scebba).

${ }^{1}$ These authors equally contributed to this paper as first author.
}

a regular basis. Traditionally this is based entirely on the evaluation of various physical and chemical variables in water and sediment, occasionally including the assessment of contaminant levels in biota. However, the environmental level of pollutants will not generally give any information about actual effects on the biological systems (Lam and Gray, 2003). Approaches based on monitoring the biological effects rather than detecting and quantifying pollutants are needed. Several studies have tried to focus on the possible adverse effects in terms of cytotoxicity and genotoxicity of nanoparticles in living organisms, both animals (Aye et al., 2013; Peng et al., 2013; Tang et al., 2013) and plants (Bandyopadhyay et al., 2015; Moon et al., 2014; Rico et al., 2015) including, recently, marine organisms (Blickley et al., 2014; Książyk et al., 2015; Mackevica et al., 2015; Tang et al., 2014). Indeed, an increasing input of nanoparticles in the aquatic environment is expected, especially in riverine and coastal areas (Corsi et al., 2014). Cellular and molecular mechanisms taking place in model marine organisms are useful tools to assess environmental risk related to nanoparticles exposure (Matranga and Corsi, 2012). Unicellular phytoplanktonic algae represent suitable organisms for 
investigating the potential ecotoxicological risk, because they are in direct contact with the external medium. In addition, microalgae are at the base of the marine food web and could play a fundamental role in the accumulation and toxicity of nanoparticles, through their potential transfer along the food chain.

Over many years, a significant effort has been made to find upto-date methods to assess how pollutants affect ecosystems including living organisms. The use of biological markers has been proposed as a sensitive "early warning" tool for biological effect measurement in environment quality assessment (Cajaraville et al., 2000). New biomarker assays are continually being developed, but frequently they measure changes in the expression level of single proteins/enzymes or mRNAs. However it has proved that single biomarkers might not be sufficient to indicate the impact of environmental pollutants (Galloway et al., 2004) because they do not provide unambiguous answers regarding possible effect on biota. As in clinical medicine, it is clear that most pollutant effects depend on a variety of responses, rather than a single one.

Genomic and proteomic technologies have the advantage of simultaneously evaluating the expression of many genes, transcripts or proteins in a single step, finding differentially expressed genes which could be putative biomarkers. They are high throughput assays allowing large-scale analysis of the possible molecular responses.

Proteins are the functional molecules of the cell (Gygi et al., 1999) and define metabolic pathways. Therefore, relevant information about the cell response to any environmental toxicant may be obtained by monitoring changes in protein expression. Traditionally this is done by two-dimensional gel electrophoresis (2DE). In spite of being a powerful technique, 2DE has drawbacks such as a not excellent resolution of low molecular weights proteins and low throughput capacity (Beranova-Giorgianni, 2003). High throughput proteomic technologies are now available, among which the gel-free SELDI-TOF-MS. This approach utilizes chemically derivatized arrays which chromatographically bind a subset of proteins from a biological matrix of interest, thus enriching the specific proteins and increasing the sensitivity for low abundance species. TOF-MS allows the bound peptides/proteins to be profiled in a semi-quantitative manner (Tang et al., 2004). ProteinChip surfaces with various chromatographic properties are available, and subsets of proteins with common properties can therefore be easily selected and analyzed. The approach is rapid, and requires small sample volumes without special sample pre-treatment (Poon, 2007).

SELDI has been used as a proteomic profiling method in clinical and pre-clinical studies in which large number of samples are analyzed and in which more standard proteomic approaches are not suitable due to their low throughput capacity (Collins et al., 2010). Compared to 2DE, only a few studies applying SELDI in the field of environmental toxicology have been published to date (Bjørnstad et al., 2006; Gomiero et al., 2006; Larsen et al., 2006; Lee et al., 2013; Mo et al., 2013; Monsinjon et al., 2006) and only one evaluated the toxic effect of nanoparticles on Cucumis sativus seeds (Moon et al., 2014).

Recently, the toxicity of CdSe/ZnS quantum dots (QDs) on the marine diatom Phaeodactylum tricornutum has been investigated (Morelli et al., 2012, 2013). Exposure of P. tricornutum to QDs induces growth inhibition, oxidative stress, and lipid peroxidation in a dose-dependent manner. The observed toxicity can be ascribed to the nanoparticles themselves rather than to the dissolved ions released from nanoparticles, since the uptake of $\mathrm{Cd}$ ions by $P$. tricornutum cells occurs only during late stationary phase, as showed elsewhere (Morelli et al., 2015). In the present study we defined the protein expression pattern in extracts of $P$. tricornutum cells exposed to $\mathrm{CdSe} / \mathrm{ZnS}$ quantum dots, using both 2DE and SELDI-TOF MS technology. SELDI analysis detected a specific protein signature induced by QD exposure.

\section{Materials and methods}

All reagents, unless specified, were purchased from Sigma (Sigma-Aldrich, St. Louis, MO, USA).

\subsection{Quantum dots}

CdSe/ZnS core/shell quantum dots (QDs), emitting at $590 \mathrm{~nm}$, are stabilized by a hexadecylamine layer, used as a ligand coating surface, and shipped in $5 \mathrm{mg} \mathrm{mL}^{-1}$ toluene dispersion. To allow the transfer of QDs in water, the organic layer was encapsulated in a functional bilayer film composed of an amphiphilic polymer poly (styrene-co-maleic anhydride) terminated with cumene (PSMA) and ethanolamine, following the procedure reported by Lees et al. (2009) with some modifications (Morelli et al., 2012). QD concentration was measured spectrophotometrically $\left(\varepsilon_{569}=1.6 \times\right.$ $10^{5} \mathrm{M}^{-1} \mathrm{~cm}^{-1}$, provided by the manufacturer). Total $\mathrm{Cd}$ was measured by Atomic Absorption Spectrometry (Perkin Elmer, Ueberlingen, Germany), after acidification with $\mathrm{HNO}_{3}(0.3 \% \mathrm{v} / \mathrm{v})$. QD and total $\mathrm{Cd}$ concentrations in the stock suspension were $1.3 \mu \mathrm{M}$ and $620 \mu \mathrm{M}$, respectively. The size of the bilayer encapsulated QDs was $17 \pm 3 \mathrm{~nm}$, as stated by fluorescence correlation spectroscopy measurements (Morelli et al., 2013). Stable suspensions of watersoluble QDs were stored in the dark at $+4{ }^{\circ} \mathrm{C}$ for a maximum of 3 months and used for the experiments with algae. Water was purified by a Milli-Q system from Millipore (Vimodrone, Italy).

\subsection{P. tricornutum growth and exposure conditions}

The unicellular marine diatom $P$. tricornutum (Bohlin) used in this study was obtained from the Culture Collection of Algae and Protozoa (Dunstaffnage Marine Laboratory, UK). Stock cultures were grown in axenic conditions at $21 \pm 1^{\circ} \mathrm{C}$ and fluorescent daylight $\left(100 \mu \mathrm{mol}\right.$ photons $\left.\mathrm{m}^{-2} \mathrm{~s}^{-1}\right)$ in a 16:8 light-dark cycle. Culture medium was natural seawater enriched with $\mathrm{f} / 2$ medium (Guillard, 1975) modified to obtain a f/10 medium as far as trace metal concentration is concerned. Seawater was collected in an uncontaminated area, filtered through $0.2 \mu \mathrm{m}$ membrane filters (Millipore) and stored in the dark at $+4^{\circ} \mathrm{C}$. Exponential growth was maintained by inoculating cells weekly into fresh sterilized medium. Cell density was measured by recording the optical density of chlorophyll at $680 \mathrm{~nm}\left(\mathrm{OD}_{680}\right)$ by UV/Vis spectrophotometer (JASCO V-550, Lecco, Italy). A standard curve of $\mathrm{OD}_{680}$ vs cell number was generated to convert the optical density of chlorophyll to cell number, measured by haemocytometer.

The effects of QDs were evaluated by exposing P. tricornutum cultures to $2.5 \mathrm{nM}$ QDs in two successive exposure cycles. For the first exposure cycle, algae from a stock culture were inoculated in fresh medium (volume $=400 \mathrm{~mL}$ ) at an initial cell density of $5 \times 10^{4}$ cells $\mathrm{mL}^{-1}$ and spiked with QDs. $\mathrm{OD}_{680}$ values of the algal cultures were measured daily until they reached $\mathrm{OD}_{680} \approx 0.25$, corresponding to $2 \times 10^{6}$ cells $\mathrm{mL}^{-1}$ (late exponential phase, 7-8 days). An aliquot of this culture (calculated to contain $4-6 \times 10^{8}$ cells) was filtered $(1.2 \mu \mathrm{m}$, Millipore) and the harvested algae stored at $-80^{\circ} \mathrm{C}$ until use for proteomic analysis (algae-QD1). For the second exposure cycle, suitable aliquots of the first culture were inoculated in fresh medium with $2.5 \mathrm{nM}$ QDs to obtain an initial cell density of $5 \times 10^{4}$ cells $\mathrm{mL}^{-1}$ (usually $10 \mathrm{~mL}$ in $400 \mathrm{~mL}$ ), and the growth was monitored for 4 days. At this time, algae were harvested as described above, stored at $-80{ }^{\circ} \mathrm{C}$ and used for proteomic analysis (algae-QD2). Control cultures (no QDs added) were always used in parallel. Three biological replicates of exposure to QDs were carried out. The specific growth rate, $\mu$, was 
estimated using the following growth equation (Guillard and Sieracki, 2005): $\mu=\ln \left(N_{1} / N_{0}\right) /\left(t_{1}-t_{0}\right)$, where $N_{0}$ and $N_{1}$ are the cell densities (cells $\mathrm{mL}^{-1}$ ) at time zero $\left(t_{0}\right)$ and $96 \mathrm{~h}\left(t_{1}\right)$ after the addition of $2.5 \mathrm{nM}$ QDs, respectively. The growth inhibition, $I$, was determined using the specific growth rate of control, $\mu_{\mathrm{c}}$, and that of exposed cultures, $\mu_{\exp }$, according to this formula: $I=100 \mathrm{x}$ $\left(\mu_{\mathrm{c}}-\mu_{\mathrm{exp}}\right) / \mu_{\mathrm{c}}$. One-way Anova-test and a post-hoc analysis of variance (Tukey test) were conducted using the OriginPro 7.5 SR0 software (Origin Lab Corporation, MA, USA).

\subsection{Protein extraction}

Proteins were extracted from frozen algae using TRIzol ${ }^{\text {Ex }}$ Reagent (Invitrogen, Life Technologies, CA, USA), following the manufacturer's instructions. Frozen cells $\left(2-6 \times 10^{8}\right)$ were suspended in $1 \mathrm{~mL}$ of Trizol and disrupted by sonication (Sonopuls Ultrasonic Homogenizer, Bandelin) for $3 \mathrm{~min}$ with a repeating duty cycle of $0.3 \mathrm{~s}$ on ice. After sonication, samples were treated with $0.2 \mathrm{~mL}$ of chloroform, mixed vigorously by hand, incubated at room temperature for $15 \mathrm{~min}$ and centrifuged for $20 \mathrm{~min}$ at $12,000 \mathrm{xg}$, at $4{ }^{\circ} \mathrm{C}$. After RNA and DNA removal, isopropanol was added to the phenol-ethanol phase to precipitate proteins. Successively the protein pellet was washed three times with $0.3 \mathrm{M}$ guanidine hydrochloride in $95 \%$ ethanol, once with $100 \%$ ethanol and finally suspended in 9.5 M urea and 2\% CHAPS. Proteins were solubilized by gentle shaking at room temperature for about 1hour. Insoluble material was removed by centrifugation $\left(10,000 x g\right.$ for $15 \mathrm{~min}$ at $\left.4{ }^{\circ} \mathrm{C}\right)$. Protein concentration was determined by Bradford method (Bradford, 1976), using bovine serum albumin as standard.

\subsection{Two dimensional gel electrophoresis (2-DE) and gel image analysis}

For the first dimension, equal amounts of proteins (80 $\mu \mathrm{g}$ per sample) were dissolved in rehydration buffer composed by $8 \mathrm{M}$ Urea, 2\% CHAPS, 0.2\% DTT, and 2\% IPG buffer pH 4-7 (Amersham Bioscience) to a final volume of $250 \mu \mathrm{L}$. Trace quantities of bromophenol blue were also added, to obtain colored samples. Protein samples were loaded on ImmobilineDryStrip $11 \mathrm{~cm} \mathrm{pH} \mathrm{4-7} \mathrm{NL}$ (Amersham Bioscience). Following overnight passive rehydration, isoelectric focusing was performed at $45 \mathrm{kVh}$ and $15^{\circ} \mathrm{C}$ for $16 \mathrm{~h}$, using the Multiphor II apparatus (Amersham Biosciences) equipped with EPS $3500 \mathrm{XL}$ power supply (Pharmacia). After isoelectric focalization, focused strips were frozen at $-80^{\circ} \mathrm{C}$. Before the second dimension separation, strips were equilibrated for $15 \mathrm{~min}$ in $50 \mathrm{mM}$ Tris- $\mathrm{HCl}$ buffer ( $\mathrm{pH} 8.8$ ), containing 30\% glycerol, $6 \mathrm{M}$ urea, $4 \%$ SDS and 2\% DTT, to reduce proteins. Subsequently, proteins were alkylated for $15 \mathrm{~min}$ in $50 \mathrm{mM}$ Tris- $\mathrm{HCl} \mathrm{pH} \mathrm{6.8,} \mathrm{con-}$ taining 30\% glycerol, $6 \mathrm{M}$ urea, $4 \%$ SDS, and 3\% iodoacetamide. Strips were loaded on the top of $14 \% \mathrm{w} / \mathrm{v}$ polyacrylamide gel and covered with $0.5 \%$ agarose. SDS-PAGE vertical electrophoresis was performed with Hoefer SE 600 Ruby apparatus, equipped with $3000 \mathrm{Xi}$ power supply (Bio-Rad Laboratories). Electrophoresis was carried out at $9{ }^{\circ} \mathrm{C}$ in $50 \mathrm{mM}$ Tris, $193 \mathrm{mM}$ glycine, and 0.1\% SDS, at $5 \mathrm{~mA} /$ gel for $30 \mathrm{~min}$, followed by $30 \mathrm{~mA} /$ gel for about $4 \mathrm{~h}$. At the end of the run, gels were treated with fixing solution ( $40 \%$ methanol, $10 \%$ acetic acid) and stained with Coomassie Brilliant Blue G-250. Control and exposed sample pairs were always run together to minimize the effects of instrumental variations on protein migration along the gel. Gels were scanned and the 16 bit images were aligned, filtered to remove speckling, backgroundsubtracted, and compared using SameSpots analysis software (Totallab).

\subsection{SELDI-TOF-MS}

\subsubsection{Protein profiling}

The ProteinChip arrays were purchased from Bio-Rad (BioRad Laboratories, Hercules, CA, USA). In a preliminary experiment $P$. tricornutum extracts were applied to four different array types with their appropriate binding buffers. We tested the weak cation exchange (CM10) array with $100 \mathrm{mM}$ sodium acetate buffer ( $\mathrm{pH} 4)$, the strong anion exchange (Q10) array with $100 \mathrm{mM}$ Tris $\mathrm{HCl}$ buffer ( $\mathrm{pH} 8.0$ ), the hydrophobic (H50) array with $10 \% \mathrm{ACN} / 0.1 \%$ TFA buffer and finally the Immobilized Metal Affinity Capture (IMAC30) array charged with copper sulfate, with the binding buffer $100 \mathrm{mM}$ sodium phosphate/500 mM sodium chloride $(\mathrm{pH}$ 7.0).

Each sample, corresponding to $10 \mu \mathrm{g}$ of total proteins, was loaded in triplicate on arrays. Samples were mixed with each binding buffer to the final volume of $150 \mu \mathrm{l}$ and loaded onto preequilibrated spot surfaces. After $30 \mathrm{~min}$ incubation with horizontal shaking at room temperature, the unbound proteins were washed out in three steps with $200 \mu \mathrm{l}$ of the corresponding buffer and $200 \mu \mathrm{l}$ of HPLC-grade water was applied once to remove salts. Finally, $1 \mu$ of saturated sinapinic acid (SPA, BioRad Laboratories) in 50\% ACN (Aldrich, Sigma-Aldrich) and 0.5\% TFA (Fluka, SigmaAldrich) was added twice to each spot on the chip and allowed to dry.

\subsubsection{Data acquisition and analysis}

The ProteinChips were analyzed using a linear TOF mass spectrometer, PCS 4000 (Ciphergen, USA), with the following protocols. Protocol 1: laser power $3250 \mathrm{~nJ}$, matrix attenuation 2500 , focus mass 10000 , sample rate 800 and $25 \%$ spot surface fired for ion profiling between the mass/charge $(\mathrm{m} / \mathrm{z})$ range of $0-$ 25000. Protocol 2: laser power 4000 nJ, matrix attenuation 2500, focus mass 30000 , sample rate 800 and $25 \%$ spot surface fired for ion profiling between the mass/charge $(\mathrm{m} / \mathrm{z})$ range of $25000-$ 50000. Using ProteinChip Data Manager 3.5 software (BioRad Laboratories), spectra were externally calibrated with ProteinChip All-in 1 peptide standard (BioRad Laboratories), baseline subtracted, mass aligned and normalized using the total ion current within the $\mathrm{m} / \mathrm{z}$ range $3000-30,000$ for the low mass proteins and 25000-50000 for the high mass proteins. Qualified mass peaks (signal/noise, $\mathrm{S} / \mathrm{N}>5$ ) were auto-detected. Peak clusters were completed using a second pass peak selection $(\mathrm{S} / \mathrm{N}>2$, within $0.3 \%$ mass window) with minimum peak threshold $20 \%$ of all spectra and estimated peaks added. We obtained a cluster list for each sample in every ProteinChip. Relative peak intensities (from three replicate determinations for each sample) were compared between control and quantum dots groups using control as reference group. Peaks variation in intensity was evaluated by Mann-Whitney $U$ test and a $p$-value less than 0.05 was accepted as statistically significant.

A principal component analysis (PCA) was performed with logtransformed data and correlation matrix. Protein Chip data manager software used PCA to visualize spectra in three-dimensional graphs that illustrated relationships between spectra based on their expression profiles.

\section{Results and discussion}

\subsection{Toxicity of QDs to P. tricornutum}

Exposure of $P$. tricornutum to QDs $(0.5-2.5 \mathrm{nM})$ induces a dosedependent inhibition of growth rate concomitant to reactive oxygen species (ROS) production enhancement, activation of antioxidant enzymes and lipid peroxidation (Morelli et al., 2013). In 
Table 1

Specific growth rate $\left(\mu\right.$, day $\left.^{-1}\right)$ at $96 \mathrm{~h}$ and relative growth inhibition in $P$. tricornutum cultures exposed to QDs. Each result is the mean value \pm standard deviation $(n=9)$ of three experiments. Data were analyzed by one-way ANOVA.

\begin{tabular}{lll}
\hline Sample & $\boldsymbol{\mu}\left(\mathbf{d a y}^{-\mathbf{1}}\right)$ & \% Inhibition \\
\hline Control & $0.95 \pm 0.06$ & - \\
Algae-QD1 & $0.33 \pm 0.11^{*}$ & 65 \\
Algae-QD2 & $0.86 \pm 0.04$ & 10 \\
\hline
\end{tabular}

${ }^{*}$ Indicates values significantly different from the control and algae-QD2 $(p<0.01$; Tukey test).

the present paper, we conducted experiments at $2.5 \mathrm{nM}$ QDs for two successive cycles of exposure to investigate the effects at the molecular level on chronically exposed P. tricornutum cultures. After $96 \mathrm{~h}$, algae exposed to QDs in the first cycle (algae-QD1) exhibited a significant decrease (65\%) of the growth rate (Table 1), highlighting an inhibition of cell division. The growth rate seen in the second exposure cycle (algae-QD2) was similar to that of control (Table 1) and significantly higher than that of the first cycle $(p<0.01)$. To rule out that the decrease in sensitivity to QDs was caused by cadmium possibly released from QDs, we checked that pre-exposure to $1.2 \mu \mathrm{M} \mathrm{CdCl}$ (concentration equivalent to that resulting from a complete degradation of $2.5 \mathrm{nM}$ QDs) did not affect the growth rate of QD exposed algae (SM Fig. 1, Supplementary Materials). We verified that algae exposed to $\mathrm{CdCl}_{2}$ exhibited a growth curve similar to that of the control, and that algae pre-treated with $\mathrm{Cd}$ and exposed to $2.5 \mathrm{nM}$ QDs behaved differently from algae-QD2, proving that dissolved Cd was not sufficient to establish protection against QD exposure. Furthermore, our previous results show that at the 4th day of growth the uptake of free Cd was negligible, as confirmed also by the undetectable level of phytochelatins, biomarkers for the presence of intracellular free Cd (Morelli et al., 2015). The higher growth rate of algae in the second exposure experiment, as compared to the first one, showed that prolonged exposure rendered algae less sensitive to the toxic effects of QDs. This finding suggested that exposed algae activate defense mechanisms, which can be maintained in subsequent generations. Previous experiments carried out with the marine diatom Thalassiosira pseudonana show that the interaction of QDs with algae increases the protein synthesis inducing an enrichment of the protein fraction of extracellular polymeric substances (EPS), which appears to mitigate QD toxicity (Zhang et al., 2013). For these reasons, we hypothesized that changes in protein expression might be involved in the activation and maintenance of defense mechanisms in response to QD exposure. To verify this hypothesis, we investigated the pattern of proteins synthetized by QD-exposed algae using 2DE and SELDI-TOF-MS.

\subsection{Two dimensional gel electrophoresis protein profiling}

Protein expression profiles obtained by 2DE of control, algaeQD1 and algae-QD2 were compared. 2DE was performed on three independent biological replicates for each group. Comparison of spot intensities, normalized for total intensity of all valid spots on the gel, detected approximately 1800 non matching spots indicating that exposure to QDs extensively changed the pattern of protein expression. The statistical analysis indicated 36 spots with intensity change greater than 2 -fold and $p$-value $\leq 0.05$, based on Anova $t$ test (Fig. 1A). PCA showed a clear separation between the data obtained from the three groups (Fig. 1B). The dendrogram produced by correlational analysis illustrated that the branching between control and exposed algae precedes that observed between algae-QD1 and algae-QD2 (Fig. 1C), indicating a greater similarity between the profiles of the two groups of exposed cells. SM Table 1 (Supplementary Materials) reports a complete list of
A
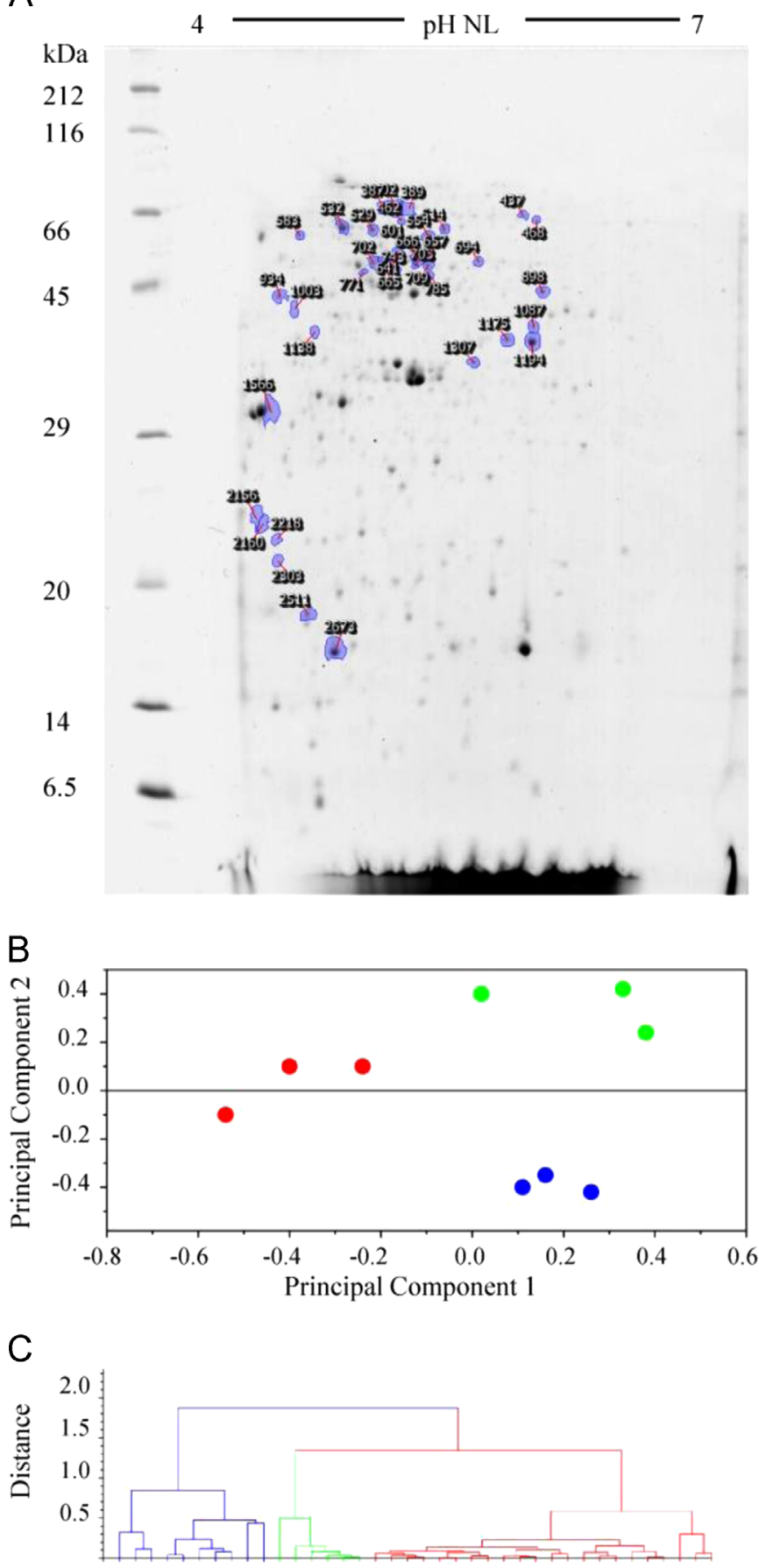

Fig. 1. Representative $2 \mathrm{DE}$ gel of $P$. tricornutum algae exposed to $2.5 \mathrm{nM} \mathrm{CdSe} / \mathrm{ZnS}$ quantum dots. (A) Protein spots significantly changing in relative intensity $(\geq 2$ fold, up or down; $p \leq 0.05$ ) are indicated by the spot number assigned by the gel analysis software. On the left, molecular weight markers are reported. Nonlinear (NL) pH range is indicated along the top axis. (B) PCA plot showing the gel clusters; blue circle, control; green circle, algae-QD1; red circle, algae-QD2. (C) Dendrogram produced by correlation analysis showing branching among control (blue), algaeQD1 (green) and algae-QD2 (red). (For interpretation of the references to color in this figure legend, the reader is referred to the web version of this article.)

the significantly different spots and statistical analysis details. As compared to control, algae-QD1 showed 10 up-regulated and 6 down-regulated proteins, and algae-QD2 showed 24 up-regulated and 5 down-regulated proteins. Among the significantly different spots, 4 up-regulated and 5 down-regulated spots were common to the two groups of exposed samples. If one compares 
algae-QD1 and algae-QD2 spots versus control, it is possible to notice that the former presented a lower number of changed spots with an higher fold change. Overall, the algae exposed to QDs presented a higher number of up-regulated proteins, mainly with a high molecular weight, with respect to control cells. Some downregulated proteins appeared between 45 and $14 \mathrm{kDa}$, whereas just few spots were detected in the molecular weight range below $14 \mathrm{kDa}$. The proteomic analysis indicated that the first exposure to QDs changed expression of specific proteins and, as long as the exposure went on, alterations involved a larger number of proteins, presumably allowing algae to survive despite the presence of the pollutant.

To efficiently resolve the molecular weight range below $14 \mathrm{kDa}$, we attempted an in depth analysis by SELDI-TOF technique to reveal differences in the protein profile and, eventually, use them as specific biomarkers of exposure to QDs.

\subsection{SELDI-TOF-MS protein profiling}

As described in Section 3.2, 2DE showed for algae-QD2 a high number of proteins differentially regulated, thus suggesting that the mechanism of adaptation to nanoparticles exposure requires increased protein synthesis. For this reason we compared control and algae-QD2 using SELDI.

In a preliminary test experiment using four ProteinChips with different array chemistries, we aimed at selecting the most appropriate retention surface for the "signature" to nanoparticles exposure. We used the CM10, Q10, H50 and IMAC30 surfaces, as described in Section 2.5, and compared the protein profiles in the molecular weight range $0-25 \mathrm{kDa}$. All the surfaces revealed quantitative differences between treated and untreated algae (data not shown). Nevertheless, with both anionic and cationic exchange surfaces, we observed a larger number of differentially expressed peaks, with both qualitative and quantitative differences, and a better reproducibility compared to the other ProteinChip surfaces. Moreover, this analysis revealed many peaks with considerable level of intensity between 3 and $10 \mathrm{kDa}$, a range which is generally not well resolved by 2DE. Below $14 \mathrm{kDa}$ few spots were observed by $2 \mathrm{DE}$ and almost no spot was visible under $6.5 \mathrm{kDa}$ (Fig. 1A). We therefore scaled the experiment up by using only Q10 and CM10 ProteinChips.

The peaks differentially expressed between control and algaeQD2 groups, revealed both by Q10 and CM10, are listed in Table 2. A heat map shows the expression levels of all significant peaks for each sample, calculated as the mean of three replicate measurements (Fig. 2). The best results were obtained by using the Q10 ProteinChip array, which exhibited a higher reproducibility and a larger number of differentially expressed peaks. Nevertheless, some of the results obtained with CM10 confirmed and reinforced those achieved with Q10. Using Q10, the low molecular weight range appeared to be the most interesting region in terms of resolution and number of peaks. In this range, among ten differentially expressed peaks, eight were down-regulated and two upregulated in the algae-QD2 group (Fig. 2A and Table 2). In the range $25-50 \mathrm{kDa}$ (high molecular weight), one peak was downregulated and two peaks were up-regulated in exposed cells (Fig. 2A and Table 2). The peak clusters at $\mathrm{m} / \mathrm{z} 4374$ and 8774 were up-regulated in the exposed cells. In turn, we observed a wide down-regulation in the regions around 6500 and $6900 \mathrm{Da}$, as shown in Fig. 2A, with two main peaks at m/z 6504 and 6925, and associated peaks around these two (Fig. $3 \mathrm{~A}$ ). The two main peaks might represent two protein/peptides and the others, modified forms. Also the peak at $\mathrm{m} / \mathrm{z} 4949$ resulted down-regulated in exposed cells, as well as that at $\mathrm{m} / \mathrm{z} 30016$ in the high molecular weight analysis, while peaks at $\mathrm{m} / \mathrm{z} 31086$ and 31263 turned out to be up-regulated (Fig. 2A).
Table 2

Differentially expressed peaks in $P$. tricornutum culture exposed to quantum dots compared to control, using the Q10 and CM10 Proteinchips. Intensities were compared with non parametric Mann-Whitney $U$ test and differences were significant per $p<0.05$.

\begin{tabular}{|c|c|c|c|}
\hline \multirow[t]{2}{*}{$\mathrm{m} / \mathrm{z}$} & \multicolumn{2}{|c|}{ Q10 Intensities (mean \pm S.D.) } & \multirow[t]{2}{*}{ Fold $(\mathrm{QD} / \mathrm{C})$} \\
\hline & Control & Quantum dots & \\
\hline 4374 & $4.04(0.4)$ & $12.24(6.7)$ & $3.03 \uparrow$ \\
\hline 4949 & $10.96(1.1)$ & $7.9(2.2)$ & $0.72 \downarrow$ \\
\hline 6458 & $26.26(2.6)$ & $20.03(3.0)$ & $0.76 \downarrow$ \\
\hline 6489 & $78.01(13.5)$ & $49.68(10.6)$ & $0.63 \downarrow$ \\
\hline 6530 & $50.80(13.06)$ & $32.74(5.4)$ & $0.64 \downarrow$ \\
\hline 6562 & $18.77(1.8)$ & $15.61(1.6)$ & $0.83 \downarrow$ \\
\hline 6894 & $13.12(1.9)$ & $7.62(1.5)$ & $0.58 \downarrow$ \\
\hline $6909^{*}$ & $32.81(7.4)$ & $20.83(4.2)$ & $0.63 \downarrow$ \\
\hline 6925 & $115.96(27.0)$ & $69.70(14.5)$ & $0.60 \downarrow$ \\
\hline 8774 & $2.55(0.2)$ & $4.62(2.07)$ & $1.81 \uparrow$ \\
\hline 30016 & $0.527(0.08)$ & $0.317(0.132)$ & $0.60 \downarrow$ \\
\hline 31086 & $0.552(0.126)$ & $0.802(0.057)$ & $1.45 \uparrow$ \\
\hline 31263 & $0.721(0.124)$ & $0.984(0.148)$ & $1.36 \uparrow$ \\
\hline \multirow[t]{2}{*}{$\mathrm{m} / \mathrm{z}$} & \multicolumn{2}{|c|}{ CM10 Intensities (mean \pm S.D.) } & Fold $(\mathrm{QD} / \mathrm{C})$ \\
\hline & Control & Quantum dots & \\
\hline 6441 & $7.37(2.4)$ & 3.38 (1.9) & $0.46 \downarrow$ \\
\hline 6877 & $6.44(2.8)$ & $3.01(1.4)$ & $0.46 \downarrow$ \\
\hline $6908^{*}$ & $10.88(3.9)$ & $5.55(2.9)$ & $0.51 \downarrow$ \\
\hline 8660 & $16.35(0.6)$ & $9.8(1.4)$ & $0.59 \downarrow$ \\
\hline 9291 & $2.49(0.4)$ & $4.12(1.5)$ & $1.65 \uparrow$ \\
\hline 11744 & $0.928(0.5)$ & $1.592(0.16)$ & $1.71 \uparrow$ \\
\hline 48188 & $0.112(0.01)$ & $0.235(0.13)$ & $2.09 \uparrow$ \\
\hline
\end{tabular}

* Peak which was found differentially regulated both by Q10 and CM10 Proteinchips.

With CM10 ProteinChip, seven protein peaks were differentially regulated, of which four were down-regulated and three upregulated in exposed cells (Table 2). It is noteworthy that a general down-regulation in the regions around 6500 and 6900 Da was observed also with this surface chemistry (Fig. 3B). The main peaks at $\mathrm{m} / \mathrm{z} 6504$ and 6925 were also detected with this ProteinChip, even though the differences in expression level were not significant. Even more interesting is the fact that the peak with $\mathrm{m} / \mathrm{z}$ 6908, revealed with both ProteinChips, was expressed at a significantly higher level in control cells. The result seems to suggest that the common peaks bound by different surfaces could represent the same proteins/peptides which, due to their physical/ chemical properties, could have affinity for both ProteinChips (Fig. 3A and B), even if at different levels (higher intensity with Q10 than with CM10). Another interesting peak which was clearly down-regulated in exposed cells, is the one at $\mathrm{m} / \mathrm{z} 8660$ (Table 2 and Fig. 2B), whose intensity is almost halved in exposed cells. On the other hand, peaks at $\mathrm{m} / \mathrm{z} 9291,11744$, in the low molecular weight analysis, and $\mathrm{m} / \mathrm{z} 48188$ in the higher molecular weight, turned out to be more expressed in QD-treated cells (Table 2, Fig. 2B).

In our work, one of the goals was to assess whether proteomic analysis by SELDI could be used to reveal pollutant-specific responses on the base of different protein expression signatures. Is the number of differentially expressed peaks found large enough to clearly define a pattern that could distinguish different groups? We observed that the differentially expressed peaks revealed by Q10 and by CM10 ProteinChips were sufficient to discriminate samples belonging to control or quantum dot groups. Indeed a multivariate analysis by Principal Components (Fig. 4), showed that it was possible to distinguish samples belonging to control from samples belonging to QD-exposed cells. The peaks deriving from Q10 ProteinChip analysis (Fig. 4A), as expected, discriminated the two groups even better than those deriving from CM10 
A

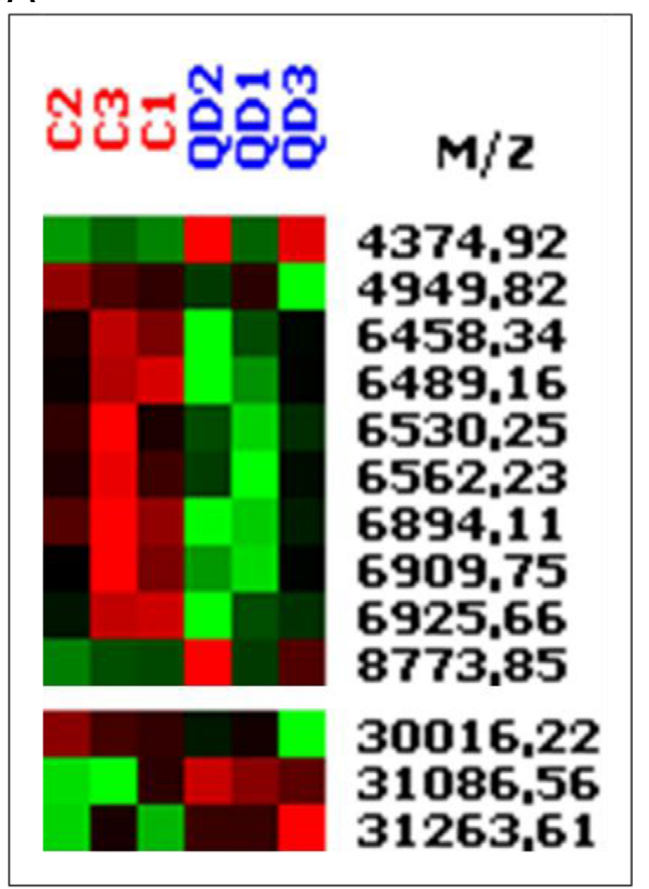

B
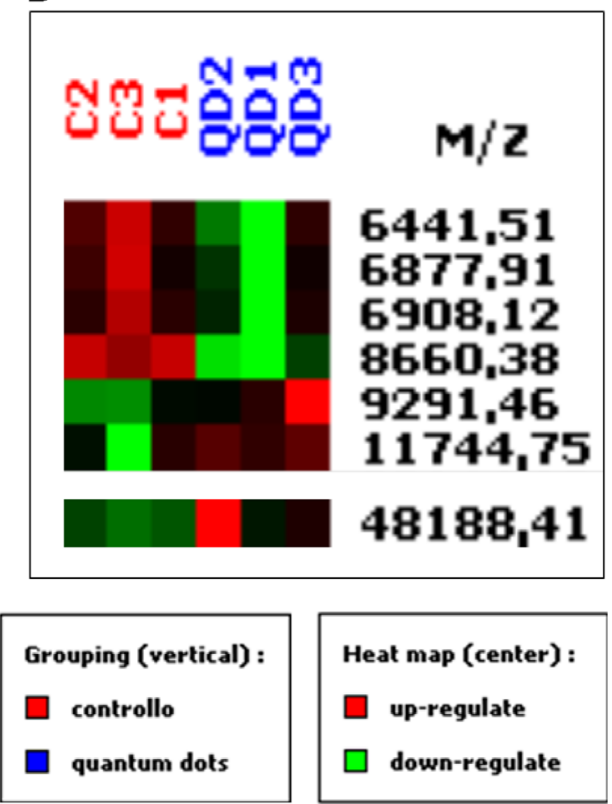

Fig. 2. Heat map of proteins of $P$. tricornutum algae showing significantly different expression upon exposure of $2.5 \mathrm{nM} \mathrm{CdS/ZnS}$ quantum dots nanoparticles, assessed by using Q10 (A) and CM10 (B) ProteinChips $(p<0.05)$.

(Fig. 4B). As also reported in other papers in which the effects of environmental pollutant on protein expression were evaluated by SELDI-TOF-MS, it is possible to efficiently discriminate between samples exposed to different environmental conditions on the basis of a set of differentially expressed peaks (Moon et al., 2014; Park et al., 2015).

In the present study, we showed that algae exposed to QDs for several generations did not differ significantly in terms of growth rate from control culture (Table 1). Despite this, these algae revealed a different profile with SELDI, indicating that common biological endpoints could not be distinctive enough to reveal the effects induced by the exposure to nanoparticles.

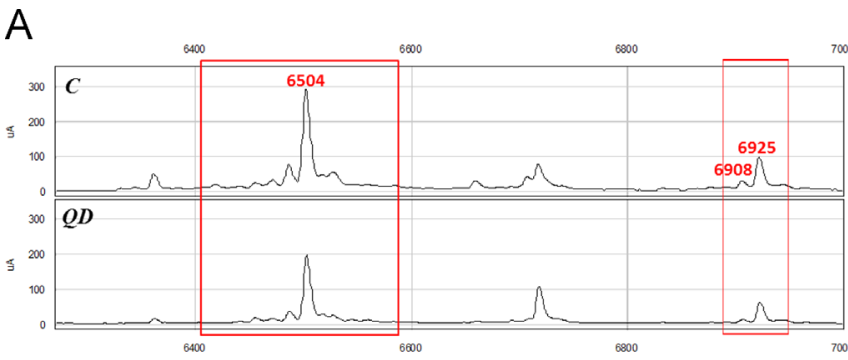

B

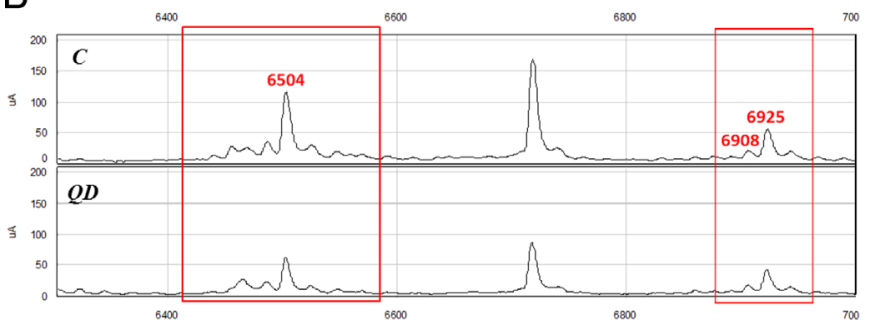

Fig. 3. Characteristic SELDI-TOF mass spectra in the region between $\mathrm{m} / \mathrm{z} 6000$ and 7000 Da for proteins of $P$. tricornutum exposed to CdSe/ZnS nanoparticles, obtained with Q10 (A) and CM10 (B) ProteinChips. A general downregulation in QD-exposed cultures was observed (squared areas). Peak at $\mathrm{m} / \mathrm{z} 6908$ was found differentially expressed with both ProteinChips $(p<0.05)$.
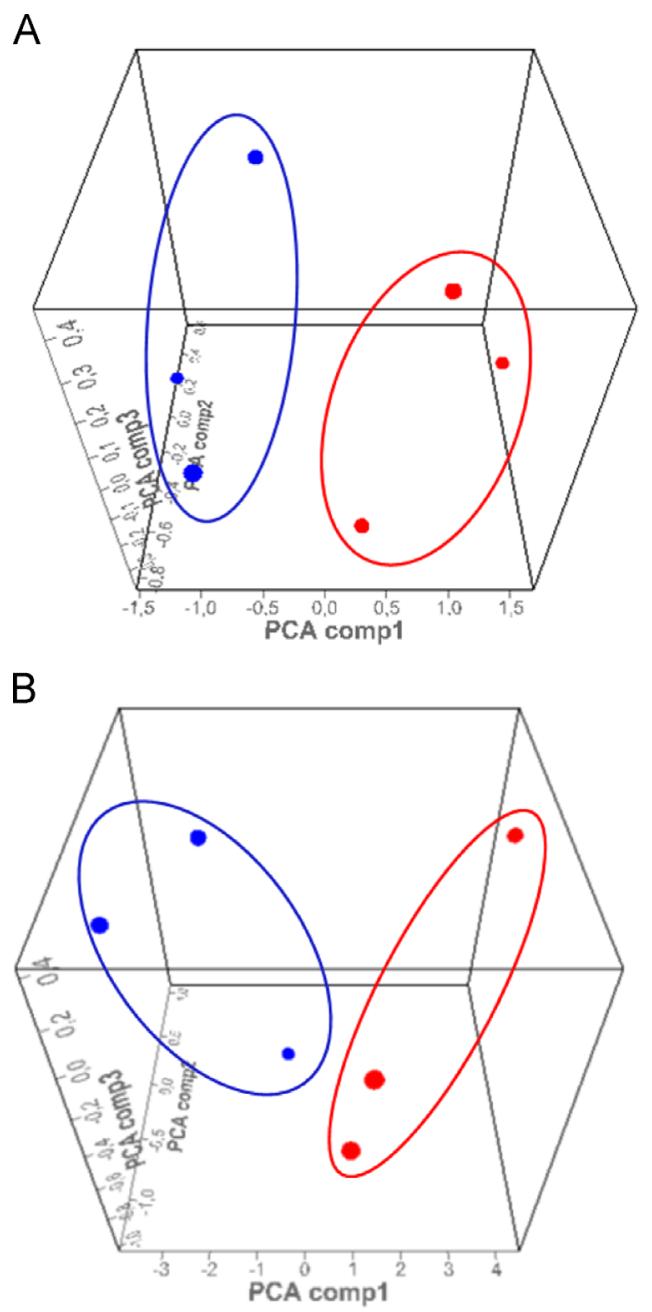

Fig. 4. PCA plot of $P$. tricornutum algae exposed to $2.5 \mathrm{nM} \mathrm{CdS} / \mathrm{ZnS}$ nanoparticles (NPs), using the Q10 (A) and CM10 (B) ProteinChips in conjunction with SELDI-TOF MS analysis. Blue circle, control; red circle, $2.5 \mathrm{nM}$ QDs (algae-QD2). 
Traditional endpoints, such as growth curves (Moon et al., 2014; Morelli et al., 2013, 2012) or other commonly used biomarkers such as the antioxidant molecules (Lee et al., 2013, 2008; Mukherjee et al., 2014) or metal chelating compounds (Gomes et al., 2011), which are reported to be activated as a response to stress induced by nanoparticles, can be useful parameters, but are too unspecific for the kind of stress and quite time-consuming to be measured. In recent papers (Moon et al., 2014; Park et al., 2015), it was demonstrated the ability of SELDI-TOF-MS to discriminate, by protein profiles, even slightly different forms of the same kind of pollutant, thus confirming the superior capability of SELDI in detecting biomarkers that can be used as an early alert for the presence of toxic substances in the environment.

Another interesting goal could be the comparison between the protein profiles below $50 \mathrm{kDa}$ of algae-QD2 and algae-QD1 using SELDI-TOF-MS. The preliminary data obtained with SELDI analysis (data not shown) would induce us to believe that algae-QD1 are more similar, based on protein profile, to algae-QD2 than to control. In agreement with these preliminary results, the clustering analysis performed with 2DE data (Fig. 1C), showed a greater similarity between samples from algae-QD1 and algae-QD2 than from control samples. On the other hand, 2DE analysis showed that algae-QD1 exhibited few differences of protein expression compared to both control and algae-QD2. Therefore it can be postulated that different mechanisms and proteins could be involved in the response to the acute (algae-QD1) versus chronic (algae-QD2) exposure. Additional and more detailed analyses are necessary to confirm this hypothesis.

\section{Conclusions}

To our knowledge, this is the first report which uses SELDI-TOFMS to identify biomarkers in marine microalgae exposed to nanoparticles. Specifically the aim of our work was to find an innovative method to characterize differences in the profile of low molecular weight proteins (below $50 \mathrm{KDa}$ ) between exposed- and non-exposed cells. Finding a protein pattern specific for exposure to polluted environments, obtainable with fast and high throughput analyses, could ensure a rapid and early monitoring, predictive of pollution before the appearance of visible symptoms. In our experiments algae-QD2 simulate the condition of organisms that are chronically exposed to toxic environment and therefore represent a good choice to evaluate the SELDI potentiality for the analysis of chronic environmental pollution, even at sub-lethal doses.

The "proteomic signature" of a sample is a useful information for rapid classification purposes, even without characterizing the proteins involved. Undoubtedly, protein identification can be useful to understand the molecular bases of the response or for planning intervention to counteract the problem. Nevertheless, the screening of a large set of samples to evaluate environmental quality can prescind from it.

In conclusion SELDI-TOF analyses can be used, coupled to the measurement of traditional endpoints, to strengthen the information regarding environmental pollution obtained by conventional analysis.

\section{Acknowledgments}

This research was supported by the National Research Council funds. The authors gratefully acknowledge Prof. Flavio Coceani for the scientific support and Dr. Marcella Simili for the revision of English language. SameSpots software used to analyze 2DE gels was kindly provided by Totallab.

\section{Appendix A. Supplementary material}

Supplementary data associated with this article can be found in the online version at http://dx.doi.org/10.1016/j.ecoenv.2015.08.024.

\section{References}

Aye, M., Di Giorgio, C., Mekaouche, M., Steinberg, J.-G., Brerro-Saby, C., Barthélémy, P., De Méo, M., Jammes, Y., 2013. Genotoxicity of intraperitoneal injection of lipoamphiphile CdSe/ZnS quantum dots in rats. Mutat. Res. 758, 48-55. http: //dx.doi.org/10.1016/j.mrgentox.2013.09.004.

Bandyopadhyay, S., Plascencia-Villa, G., Mukherjee, A., Rico, C.M., José-Yacamán, M., Peralta-Videa, J.R., Gardea-Torresdey, J.L., 2015. Comparative phytotoxicity of $\mathrm{ZnO} \mathrm{NPs}$, bulk $\mathrm{ZnO}$, and ionic zinc onto the alfalfa plants symbiotically associated with Sinorhizobium meliloti in soil. Sci. Total Environ. 515-516C, 60-69. http://dx.doi.org/10.1016/j.scitotenv.2015.02.014.

Beranova-Giorgianni, S., 2003. Proteome analysis by two-dimensional gel electrophoresis and mass spectrometry: strengths and limitations. Trends Anal. Chem. 22, 273-281. http://dx.doi.org/10.1016/S0165-9936(03)00508-9.

Bjørnstad, A., Larsen, B.K., Skadsheim, A., Jones, M.B., Andersen, O.K., 2006. The potential of ecotoxicoproteomics in environmental monitoring: biomarker profiling in mussel plasma using ProteinChip array technology. J. Toxicol. Environ. Health A 69, 77-96. http://dx.doi.org/10.1080/15287390500259277.

Blickley, T.M., Matson, C.W., Vreeland, W.N., Rittschof, D., Di Giulio, R.T., McClellanGreen, P.D., 2014. Dietary CdSe/ZnS quantum dot exposure in estuarine fish: bioavailability, oxidative stress responses, reproduction, and maternal transfer. Aquat. Toxicol. 148, 27-39. http://dx.doi.org/10.1016/j.aquatox.2013.12.021.

Bradford, M., 1976. Rapid and sensitive method for quantification of microgram quantities of protein utilizing principle of protein-dye-binding. Anal. Biochem. $72,248-254$.

Cajaraville, M.P., Bebianno, M.J., Blasco, J., Porte, C., Sarasquete, C., Viarengo, A. 2000. The use of biomarkers to assess the impact of pollution in coastal environments of the Iberian Peninsula: a practical approach. Sci. Total Environ. 295-311. http://dx.doi.org/10.1016/S0048-9697(99)00499-4.

Collins, B.C., Sposny, A., McCarthy, D., Brandenburg, A., Woodbury, R., Pennington, S. R., Gautier, J.-C., Hewitt, P., Gallagher, W.M., 2010. Use of SELDI MS to discover and identify potential biomarkers of toxicity in InnoMed PredTox: a multi-site, multi-compound study. Proteomics 10, 1592-1608. http://dx.doi.org/10.1002/ pmic.200900608.

Corsi, I., Cherr, G.N., Lenihan, H.S., Labille, J., Hassellov, M., Canesi, L., Dondero, F. Frenzilli, G., Hristozov, D., Puntes, V., Della Torre, C., Pinsino, A., Libralato, G., Marcomini, A., Sabbioni, E., Matranga, V., 2014. Common strategies and technologies for the ecosafety assessment and design of nanomaterials entering the marine environment. ACS Nano 8, 9694-9709. http://dx.doi.org/10.1021/ nn504684k

Dow, W.-P., Huang, T.-J., 1996. Yttria-Stabilized Zirconia Supported Copper Oxide CatalystII. Effect of Oxygen Vacancy of Support on Catalytic Activity for CO Oxidation. J. Catal. 160, 171-182. http://dx.doi.org/10.1006/jcat.1996.0136.

Galloway, T.S., Brown, R.J., Browne, M.A., Dissanayake, A., Lowe, D., Jones, M.B. Depledge, M.H., 2004. Ecosystem management bioindicators: The ECOMAN project-A multi-biomarker approach to ecosystem management. Mar. Environ. Res., 233-237. http://dx.doi.org/10.1016/j.marenvres.2004.03.064.

Gomes, T., Pinheiro, J.P., Cancio, I., Pereira, C.G., Cardoso, C., Bebianno, M.J., 2011 Effects of copper nanoparticles exposure in the mussel Mytilus galloprovincialis. Environ. Sci. Technol. 45, 9356-9362. http://dx.doi.org/10.1021/ es200955s.

Gomiero, A., Pampanin, D.M., Bjørnstad, A., Larsen, B.K., Provan, F., Lyng, E., Andersen, O.K., 2006. An ecotoxicoproteomic approach (SELDI-TOF mass spectrometry) to biomarker discovery in crab exposed to pollutants under laboratory conditions. Aquat. Toxicol. 78. http://dx.doi.org/10.1016/j. aquatox.2006.02.013.

Guillard, R.R.L., 1975. Culture of phytoplankton for feeding marine invertebrates. Cult. Mar. Invertebr. Anim., 29-60. http://dx.doi.org/10.1007/ 978-1-4615-8714-9.

Guillard, R.R.L., Sieracki, M.S., 2005. Counting cells in cultures with the light microscope. In: Anderson, R.A. (Ed.), Algal Culturing Techniques. Academic Press, Amsterdam, pp. 239-252.

Gygi, S.P., Rist, B., Gerber, S.A., Turecek, F., Gelb, M.H., Aebersold, R., 1999. Quantitative analysis of complex protein mixtures using isotope-coded affinity tags. Nat. Biotechnol. 17, 994-999. http://dx.doi.org/10.1038/13690.

Kim, B.Y.S., Rutka, J.T., Chan, W.C.W., 2010. Nanomedicine. N. Engl. J. Med. 363 2434-2443. http://dx.doi.org/10.1056/NEJMra0912273.

Książyk, M., Asztemborska, M., Stęborowski, R., Bystrzejewska-Piotrowska, G., 2015. Toxic effect of silver and platinum nanoparticles toward the freshwater $\mathrm{Mi}$ croalga Pseudokirchneriella subcapitata. Bull. Environ. Contam. Toxicol. . http: //dx.doi.org/10.1007/s00128-015-1505-9

Lam, P.K.S., Gray, J.S., 2003. The use of biomarkers in environmental monitoring programmes. Mar. Pollut. Bull. . http://dx.doi.org/10.1016/S0025-326X(02) 
00449-6

Larsen, B.K., Bjørnstad, A., Sundt, R.C., Taban, I.C., Pampanin, D.M., Andersen, O.K., 2006. Comparison of protein expression in plasma from nonylphenol and bisphenol A-exposed Atlantic cod (Gadus morhua) and turbot (Scophthalmus maximus) by use of SELDI-TOF. Aquat. Toxicol. 78. http://dx.doi.org/10.1016/j. aquatox.2006.02.026.

Lee, S.E., Young-Woong, C., Mo, H.H., Son, J., Park, K., Cho, K., 2013. Endosulfaninduced biomarkers in Japanese rice fish (Oryzias latipes) analyzed by SELDITOF-MS. Int. J. Biol. Sci. 9, 343-349. http://dx.doi.org/10.7150/ijbs.5501.

Lee, W.-M., An, Y.-J., Yoon, H., Kweon, H.-S., 2008. Toxicity and bioavailability of copper nanoparticles to the terrestrial plants mung bean (Phaseolus radiatus) and wheat (Triticum Aestivum): plant agar test for water-insoluble nanoparticles. Environ. Toxicol. Chem. 27, 1915. http://dx.doi.org/10.1897/07-481.1.

Lees, E.E., Nguyen, T.L., Clayton, A.H.A., Mulvaney, P., 2009. The Preparation of colloidally stable, water-soluble, biocompatible, semiconductor nanocrystals with a small hydrodynamic diameter. ACS Nano 3, 1121-1128. http://dx.doi.org/ $10.1021 / \mathrm{nn} 900144 \mathrm{n}$

Mackevica, A., Skjolding, L.M., Gergs, A., Palmqvist, A., Baun, A., 2015. Chronic toxicity of silver nanoparticles to Daphnia magna under different feeding conditions. Aquat. Toxicol. 161C, 10-16. http://dx.doi.org/10.1016/j. aquatox.2015.01.023.

Matranga, V., Corsi, I., 2012. Toxic effects of engineered nanoparticles in the marine environment: Model organisms and molecular approaches. Mar. Environ. Res. 76, 32-40. http://dx.doi.org/10.1016/j.marenvres.2012.01.006.

Mo, H., Lee, S.-E., Son, J., Hwang, J.M., Bae, Y.J., Cho, K., 2013. Exposure of mayfly Ephemera orientalis (Ephemeroptera) eggs to heavy metals and discovery of biomarkers. Environ. Toxicol. Pharmacol. 36, 1167-1175. http://dx.doi.org/ 10.1016/j.etap.2013.10.004.

Monsinjon, T., Andersen, O.K., Leboulenger, F., Knigge, T., 2006. Data processing and classification analysis of proteomic changes: a case study of oil pollution in the mussel, Mytilus edulis. Proteome Sci. 4, 17. http://dx.doi.org/10.1186/ 1477-5956-4-17.

Moon, Y.-S., Park, E.-S., Kim, T.-O., Lee, H.-S., Lee, S.-E., 2014. SELDI-TOF MS-based discovery of a biomarker in Cucumis sativus seeds exposed to $\mathrm{CuO}$ nanoparticles. Environ. Toxicol. Pharmacol. 38, 922-931. http://dx.doi.org/10.1016/j. etap.2014.10.002.

Morelli, E., Cioni, P., Posarelli, M., Gabellieri, E., 2012. Chemical stability of CdSe quantum dots in seawater and their effects on a marine microalga. Aquat. Toxicol. 122-123, 153-162. http://dx.doi.org/10.1016/j.aquatox.2012.06.012.

Morelli, E., Salvadori, E., Basso, B., Tognotti, D., Cioni, P., Gabellieri, E., 2015. The response of Phaeodactylum tricornutum to quantum dot exposure: acclimation and changes in protein expression. Mar. Environ. Res. . http://dx.doi.org/ 10.1016/j.marenvres.2015.06.018

Morelli, E. Salvadori, E., Bizzarri, R., Cioni, P., Gabellieri, E., 2013. Interaction of $\mathrm{CdSe} / \mathrm{ZnS}$ quantum dots with the marine diatom Phaeodactylum tricornutum and the green alga Dunaliella tertiolecta: a biophysical approach. Biophys. Chem. 182, 4-10. http://dx.doi.org/10.1016/j.bpc.2013.06.007.

Mukherjee, A., Peralta-Videa, J.R., Bandyopadhyay, S., Rico, C.M., Zhao, L., GardeaTorresdey, J.L., 2014. Physiological effects of nanoparticulate $\mathrm{ZnO}$ in green peas (Pisum sativum L.) cultivated in soil. Metallomics 6, 132-138. http://dx.doi.org/ 10.1039/c3mt00064h.

Park, D.-S., Jeon, H.-J., Park, E.-S., Bae, I.K., Kim, Y.-E., Lee, S.-E., 2015. Highly selective biomarkers for pesticides developed in Eisenia fetida using SELDI-TOF MS. Environ. Toxicol. Pharmacol. 39, 635-642. http://dx.doi.org/10.1016/j. etap.2014.12.020.

Peng, L., He, M., Chen, B., Wu, Q., Zhang, Z., Pang, D., Zhu, Y., Hu, B., 2013. Cellular uptake, elimination and toxicity of $\mathrm{CdSe} / \mathrm{ZnS}$ quantum dots in HepG2 cells. Biomaterials 34, 9545-9558. http://dx.doi.org/10.1016/j. biomaterials.2013.08.038.

Poon, T.C.W., 2007. Opportunities and limitations of SELDI-TOF-MS in biomedical research: practical advices. Expert Rev. Proteomics 4, 51-65. http://dx.doi.org/ 10.1586/14789450.4.1.51.

Rico, C.M., Barrios, A.C., Tan, W., Rubenecia, R., Lee, S.C., Varela-Ramirez, A., PeraltaVidea, J.R., Gardea-Torresdey, J.L., 2015. Physiological and biochemical response of soil-grown barley (Hordeum vulgare L.) to cerium oxide nanoparticles. Environ. Sci. Pollut. Res. Int. . http://dx.doi.org/10.1007/s11356-015-4243-y

Smyder, J.A., Krauss, T.D., 2011. Coming attractions for semiconductor quantum dots. Mater. Today 14, 382-387. http://dx.doi.org/10.1016/S1369-7021(11) 70182-1.

Tang, N., Tornatore, P., Weinberger, S.R., 2004. Current developments in SELDI affinity technology. Mass Spectrom. Rev. . http://dx.doi.org/10.1002/mas.10066

Tang, S., Wu, Y., Ryan, C.N., Yu, S., Qin, G., Edwards, D.S., Mayer, G.D., 2014. Distinct expression profiles of stress defense and DNA repair genes in Daphnia pulex exposed to cadmium, zinc, and quantum dots. Chemosphere 120C, 92-99. http: //dx.doi.org/10.1016/j.chemosphere.2014.06.011.

Tang, Y., Han, S., Liu, H., Chen, X., Huang, L., Li, X., Zhang, J., 2013. The role of surface chemistry in determining in vivo biodistribution and toxicity of CdSe/ZnS coreshell quantum dots. Biomaterials 34, 8741-8755. http://dx.doi.org/10.1016/j. biomaterials.2013.07.087.

Zhang, S., Jiang, Y., Chen, C.S., Creeley, D., Schwehr, K.A., Quigg, A., Chin, W.C., Santschi, P.H., 2013. Ameliorating effects of extracellular polymeric substances excreted by Thalassiosira pseudonana on algal toxicity of CdSe quantum dots. Aquat. Toxicol. 126, 214-223. http://dx.doi.org/10.1016/j.aquatox.2012.11.012. 